University of Nebraska - Lincoln

DigitalCommons@University of Nebraska - Lincoln

Management Department Faculty Publications

Management Department

2006

\title{
Virtuous Leadership: A Theoretical Model and Research Agenda
}

Craig L. Pearce

University of Nebraska - Lincoln, cpearce2@unl.edu

David A. Waldman

Arizona State University, waldman@asu.edu

Mihaly Csikszentmihalyi

Claremont Graduate University, miska@cgu.edu

Follow this and additional works at: https://digitalcommons.unl.edu/managementfacpub

Part of the Management Sciences and Quantitative Methods Commons

Pearce, Craig L.; Waldman, David A.; and Csikszentmihalyi, Mihaly, "Virtuous Leadership: A Theoretical Model and Research Agenda" (2006). Management Department Faculty Publications. 76.

https://digitalcommons.unl.edu/managementfacpub/76

This Article is brought to you for free and open access by the Management Department at DigitalCommons@University of Nebraska - Lincoln. It has been accepted for inclusion in Management Department Faculty Publications by an authorized administrator of DigitalCommons@University of Nebraska - Lincoln. 
Published in the Journal of Management. Spirituality \& Religion, 3:1-2 (2006), pp. 60-77; doi: 10.1080/14766080609518611 Copyright (C) 2006 Routledge/Taylor \& Francis Group. Used by permission.

\title{
Virtuous Leadership: A Theoretical Model and Research Agenda
}

\author{
Craig L. Pearce \\ Claremont Graduate University \\ David A. Waldman \\ Arizona State University \\ Mihaly Csikszentmihalyi \\ Claremont Graduate University
}

\begin{abstract}
In this manuscript we attempt to shed light on the concept of virtuous leadership. We first attempt to identify the nature of virtuous leadership. Next, we specify two potential antecedents of virtuous vertical leadership. Specifically, we identify the personal characteristic of responsibility disposition as well as environmental cues as potential predictors of subsequent virtuous leadership. Moreover. we articulate how virtuous vertical leadership might result in virtuous shared leadership. We also demonstrate how both vertical and shared virtuous leadership can act as key factors in the creation of organizational learning. Importantly. we specify several important research implications of our theoretical model. Finally, we illustrate several practical considerations when it comes to developing and enhancing virtuous leadership.
\end{abstract}

Keywords: virtuous leadership frames, leadership, organizational learning 
$\mathrm{T}$

he purpose of this manuscript is to provide definition to the concept of virtuous leadership, to identify potential antecedents of virtuous leadership and to articulate its potential relationship to organizational learning. The issue of virtue in organizations has taken on more prominence in recent years. Reflecting general thinking on positive psychology (e.g., Csikszentmihaly, 1990, 1993; Seligman and Csikszentmihalyi, 2000), scholars have begun to take a keen interest in positive organizational psychology (e.g., Csikszentmihalyi, 2003; Gardner, Damon and Csikszentmihalyi, 2001). Numerous, recent high-profile corporate scandals, such as those at Enron, Worldcom, and Aldelphia, among others, have no doubt also heightened interest in the virtues, or lack thereof, demonstrated by the leaders of our organizations. Accordingly, we begin by briefly reviewing leadership theory and scholarship on organizational learning. We subsequently specify what we believe to comprise the nature of virtuous leadership in organizations. We then develop a theoretical model of virtuous leadership, including potential antecedents and outcomes. Finally, we discuss the research and practical implications of our model.

Numerous definitions of leadership have been put forth in the literature, with many focusing on influence processes used in pursuing a goal or set of goals (Sashkin, 1988; Yukl, 2002). For example, Rauch and Behling (1984: 46) defined leadership as a "process of influencing the activities of an organized group toward goal achievement." In a similar manner, House et al. (1999) posed the definition, "the ability of an individual to influence, motivate, and enable others to contribute toward the effectiveness and success of the organization ....."

Some recent definitions of leadership, however, emphasize that the influence process involves a relationship component (e.g., Lord and Brown, 2001, 2004; Waldman, House, Ramirez, and Puranam, 2001). Leadership, according to these recent definitions, entails a relationship between a leader and followers, although the relationship can be hierarchically or geographically distant and not require face-to-face interaction (Waldman and Yammarino, 1999). Pearce and colleagues (e.g., Pearce and Conger, 2003; Pearce and Manz, 2005) have built on the idea of leadership as embedded in relationships in their articulation of shared leadership theory. According to shared leadership theory, leadership can flow in multiple directions in organizations, including both up and down the vertical hierarchy as well as horizontally among peers. More specifically, shared leadership can be defined as the serial emergence of multiple leaders based on the task demands and the knowledge, skills and abilities of those involved in the task. Recent research has documented the importance of shared leadership in a wide variety of contexts includ- 
ing top management teams (Ensley and Pearce, 2000), change management (Pearce and Sims, 2002), research and development (Hooker and Csikszentmihalyi, 2003), the military (Shamir and Lapidot, 2003) and social work (Pearce, Yoo and Alavi, 2004). In sum, virtuous leadership can be displayed by formally designated, vertical leaders, as well as through shared leadership.

The concept of organizational learning has also taken on increased prominence in recent years, as scholars have attempted to link it to firm strategy and effectiveness (Senge, 1990). Crossan, Lane, and White (1999), for instance, view organizational learning as a dynamic process of change in both thought and action, characterized by the challenge between acquiring new learning, while utilizing what has already been learned. Vera and Crossan (2004) point toward linkages between leadership behavior at strategic levels, and organizational learning-especially with regard to feed-forward processes that allow a firm to innovate and renew itself. As such, organizational learning can provide a means of long-term competitive advantage.

In the text that follows, we argue that virtuous leadership is an important facilitator of learning within organizations. Virtuous leadership can establish the conditions of trust and openness that are critical to the creation and transformation of knowledge within organizations. Accordingly, in the next section we illuminate the nature of virtuous leadership by specifically considering the role of the vertical leader. Later we articulate how shared leadership might likewise be virtuous in nature.

\section{The Nature of Virtuous Leadership}

While various definitions of leadership are clearly sensible, we contend that they have not adequately specified how leadership can be virtuous in nature. The dictionary equates virtuous to righteousness and morality. As such, any definition of virtuous leadership should specifically include the pursuit of righteous and moral goals for both individuals and the organizations in which they work. Accordingly, we define virtuous leadership as distinguishing right from wrong in one's leadership role, taking steps to ensure justice and honesty, influencing and enabling others to pursue righteous and moral goals for themselves and their organizations and helping others to connect to a higher purpose.

Burns (1978) originally advanced the argument that transforming leadership is tantamount to virtuous leadership, and that both followers and leaders progress to the highest levels of moral development (Kohlberg, 1976) as a result of such leadership. That is, transformational lead- 
ers are able to progress to Kohlberg's post-conventional stage, in which they act in an independent and ethical manner, regardless of the expectations of other individuals. Along similar lines, Kuhnert and Lewis (1987) and Kuhnert (1994) outlined a constructive/developmental personality theory of understanding the world and resulting behavior on the part of leaders. This theory would suggest that transformational leaders are likely to progress to a superior stage of development, involving deeplyheld personal values and standards (e.g., integrity, justice, and maintaining the societal good). Bass and Steidlmeier (1999) also addressed moral values, suggesting that authentic transformational leaders attain advanced levels of moral development. Additionally, Turner, Barling, Epitropaki, Butcher, and Milner (2002) present evidence of an empirical relationship between leadership and moral development, according to the Kohlberg (1976) typology.

Along similar lines, Kanungo (2001) and Mendonca (2001) argued that charismatic leadership, a concept similar to transformational leadership, can be rooted in strong ethical values. The essence of this argument is that such leaders are likely to be guided by morally altruistic principles that "reflect a helping concern for others even at considerable personal sacrifice or inconvenience" (Mendonca, 2001, 268). As such, their visions are just and in sync with the demands of various stakeholders, not just shareholders - a notion to which we will return below. Further, their fortitude gives these types of leaders the courage to face risks and work at overcoming obstacles in the pursuit of goals (Mendonca, $200 \mathrm{I}$ ). We should caution, however, that as noted by previous authors (e.g., Bass and Steidlmeier, 1999; Howell and Avolio, 1992), not all leaders with charismatic appeal will have strong moral values, and indeed some may have motives leaning more toward personal power and self-aggrandizement, which we address in the following section.

\section{A Model of Virtuous Leadership and Organizational Learning}

In Figure 1 we present a model of virtuous leadership. The model has three primary features. First, we link the enactment of virtuous vertical leadership to two likely antecedents. Second, we conceptualize how virtuous vertical leadership can affect the display of virtuous shared leadership. Finally, we articulate the importance of virtuous leadership, both vertical and shared, to organizational learning. 


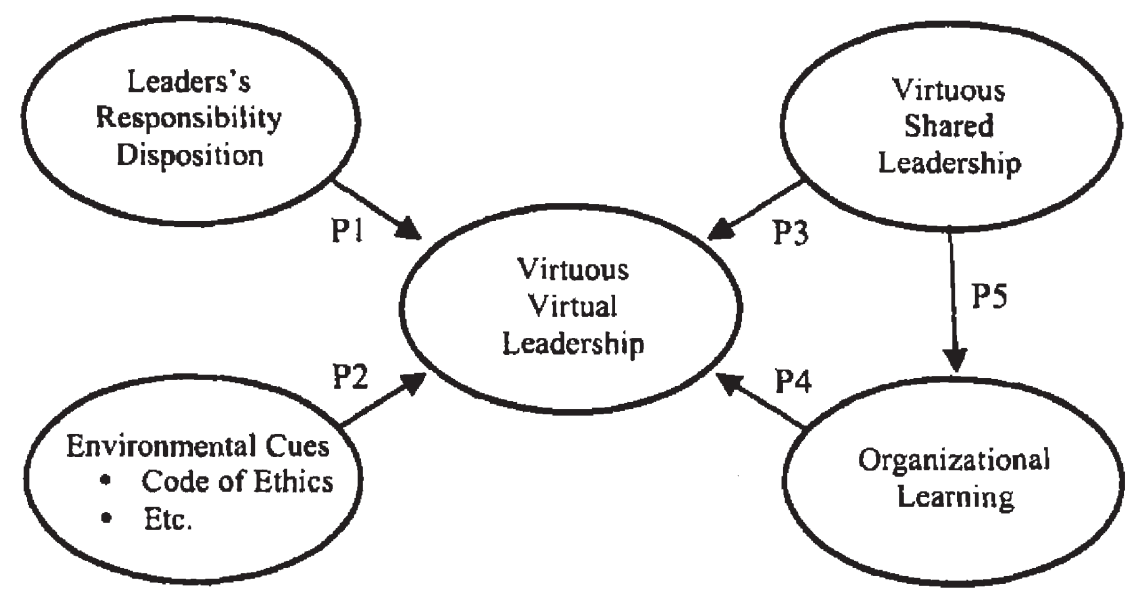

Figure 1. A model of virtuous leadership antecedents and outcomes.

\section{Antecedents of Virtuous Vertical Leadership}

We expect two broad types of antecedents of virtuous vertical leadership. On the one hand, personal characteristics should play a major role in the virtuousness of one's leadership. Accordingly, we examine the leader's responsibility disposition. On the other hand, we expect the environment to play an important role. Accordingly, we examine the role of environmental cues (e.g., ethics codes, reward systems, etc.). Below we further explicate the potential nature of these relationships.

Responsibility disposition. Leaders can be classified according to two types of need for power: (1) socialized, and (2) personalized. The key distinction between these types of need for power lies in the leader's underlying responsibility disposition. Socialized leaders tend to have a high responsibility disposition, whereas personalized leaders have a low responsibility disposition. Winter (1991) proposed that individuals with a strong sense of responsibility have beliefs and values reflecting high moral standards. a feeling of obligation to do the right thing, concern about others, and a high degree of self-judgment or critical evaluation of one's own character. These types of leaders apply restraint in their use of power, and they use their influence to achieve goals and objectives for the betterment of the collective entity, rather than for personal gain (House and Howell, 1992). Similarly, Avolio, Gardner, Walumbwa, Luthans. and May (2004) suggested that authentic leaders set a personal example of moral standards and integrity, thus building a high level of identification with the leader. 
In contrast, leaders high in a need for personalized power desire positions of power for their personal benefit, rather than the benefit of the larger group or organization (Conger, 1990; Hogan, Curphy and Hogan, 1994). Indeed, these types of leaders are often described as narcissistic: They can become extremely self-absorbed, have an exaggerated sense of self-importance. have a strong desire to be admired by others, and view the manipulation of others as a sport (Hogan, 1994; Hogan, et al. 1994; Kets de Vries, 1993; Maccoby, 2004). Such individuals raise impression management to the level of an art (Gardner and Avolio, 1998; Giacalone, Knouse, and Pearce, 1998). Accordingly, such leaders are adept at scheming ways to enhance their own image (Gardner and Avolio, 1998; Giacalone et al., 1998), and persuasively emphasize the importance of personal allegiance to them as the leader, rather than the greater organization (Hogan, et al., 1994). Indeed, these types of narcissistic leaders often have great difficulty in building a team because of their counterproductive need for personal power over others (Hogan, et al., 1994). As such, we believe the leader's responsibility disposition plays a key role in how virtuous one behaves as a leader. The following proposition more formally articulates this viewpoint.

P1. The leader's responsibility disposition will be related to how virtuously the leader behaves.

Environmental cues. Mischel (1977) articulated the concept of situational strength. Strong situations are characterized as providing very clear cues as to appropriate behavior, while weak situations are characterized as being ambiguous with regard to what constitutes appropriate behavior. While situational strength may provide cues to expected behavior, nothing guarantees that those cues will indicate virtuous behavior. Take Enron for example. At Enron there were numerous cues that continuous improvement in short-term financial numbers was paramount: Those who found ways to increase the numbers, no matter the means, were those most highly rewarded and recognized. The environmental cues at Enron were quite strong.

Nevertheless, it is possible to manage environmental cues such that they are in support of virtuous leadership. Consider, for example, the work of Manz and Sims and colleagues (e.g., Manz and Sims, 1990, 2001). These authors have specifically articulated the importance of managing one's environment in support of effective leadership. At the organizational level, cues can take on many forms, from ethics codes (e.g., Weaver, Trevino, and Cochran, 1999), to leadership selection and development systems, to the manner in which rewards are distributed. Accordingly, we propose that environmental cues will be predictive of vir- 
tuous leadership. This position is stated more formally in the following proposition.

P2. Environmental cues will be related to how virtuous the leader behaves.

\section{Likely Outcomes of Virtuous Leadership}

While many potential outcomes of virtuous leadership are likely, we focus on two specific outcomes in our model. First we articulate the potential relationship between virtuous vertical leadership on the development of virtuous shared leadership. Second, we link virtuous leadership, both vertical and shared, to organizational learning.

Virtuous vertical leadership and shared leadership. We expect virtuous vertical leadership to result in virtuous shared leadership. As defined above, the virtuous vertical leader has deep concern for equity and justice, as well as helping others to achieve moral and righteous goals. These types of vertical leaders have been labeled alternatively as either "empowering" leaders (e.g., Pearce and Sims, 2002; Pearce et al., 2003) or as "SuperLeaders" (Manz and Sims, 1990, 1991, 2001). Houghton, Neck, and Manz $(2003,133)$ specifically linked virtuous vertical leadership to the development and display of shared leadership in teams: "SuperLeadership may be viewed as the art of creating and facilitating ... shared leadership."

Bass, Waldman, Avolio and Bebb (1987) found that subordinates tended to emulate the transformational leadership they experienced from above, and labeled the phenomenon the "falling dominoes effect." More recently, Pearce and Sims (2002) identified that this domino effect applies across a wide range of leader behavior, ranging from aversive leadership - the use of threats and intimidation, and the like-to virtuous forms of leadership, such as empowering leadership. Accordingly, virtuous, vertical leadership seems likely to result in virtuous shared leadership. The following proposition more formally articulates this position.

P3. Virtuous vertical leadership is positively related to the development and display of virtuous shared leadership.

Virtuous vertical leadership and organizational learning. To better understand how virtuous vertical leadership might affect organizational learning we turn to stakeholder theory. Stakeholder theory specifies that a firm has a variety of different constituencies, such as employees, suppliers. customers. shareholders, and the broader community (Donaldson and Preston, 1995; Freeman. 1984). All of these constituencies have 
a strategic and/or moral stake in the firm, and they are guided by their own interests and values. The key issue addressed by virtuous leaders is how to enhance the welfare of the firm, while simultaneously balancing the needs of the various stakeholders. Many scholars claim that by far the most important stakeholder to which top leaders must attend are the shareholders since they are the owners of the company. However, because of their broad-ranging moral and justice values, virtuous vertical leaders will attempt to balance the interests of all stakeholders (Bass and Steidlmeier, 1999; Waldman, Siegel, and Javidan, 2005), providing a more robust framework from which to leverage the learning potential of the firm.

As an example of the effect of virtuous vertical leadership on organizational learning, Waldman et al. (2005) described the case of a CEO of a Fortune 500 company that had been trying to energize his executive leadership team and other senior managers to focus on a totally new conceptualization of the firm's strategy. Yet because of the uniqueness and change involved in the strategy, it was facing skepticism and neglect from the executive team. The CEO had organized a three-day retreat with his top 200 executives to discuss the new strategy and build commitment to its implementation. During the first day, the CEO and other speakers provided details on the new strategy and engaged in a variety of discussions. By mid-afternoon, it was clear that the CEO was not fully connecting to the group. He changed gears and started talking about how the new strategy would help the company contribute to the global fight against AIDS, specifically how the war against AIDS could benefit from the new strategy even though the company is not in the medical field.

The impact of the five-minute talk about AIDS was apparent. The mood of the group showed a discernable change. Managers started showing a stronger interest in the topic. During all formal and informal discussions that evening and the next two days, many references were made to the battle against AIDS. Upon completion of the retreat, the participants rated the discussion about AIDS as one of the highlights of the retreat. The gathering started with a large group of skeptical executives and seemed to have ended with a large group of energized and mobilized executives. The upshot is that followers may be more motivated and energized to contribute to the learning capacity of the firm, when the leadership is clearly virtuous in nature.

P4. Virtuous vertical leadership is positively related to organizational learning.

Virtuous shared leadership and organizational learning. We also expect virtuous shared leadership to result in enhanced organizational 
learning, which is consistent with extant theory. Burke, Fiore, and Salas (2003), as well as Conger and Pearce (2003), specifically link shared leadership with team-level cognition, while Vera and Crossan $(2004,227)$ purported that "the ideal leader might recognize his or her limitations and share the leadership of organizational learning."

The empirical evidence on shared leadership also suggests that it should be positively related to organizational learning. To date. studies of shared leadership have consistently linked it with positive organizational outcomes (Avolio et al., 1996; Ensley and Pearce, 2000; Hooker and Csikszentmihalyi, 2003; Pearce, 1997; Pearce and Sims, 2002; Pearce and Ensley, 2004; Shamir and Lapidot, 2003). Most of the studies have examined some dimension of performance; however. several have examined other constructs, such as team dynamics. Shamir and Lapidot (2003), for example found shared leadership to be inextricably linked to moral and ethical decision making in the military. Moreover. Pearce et al. (2004) found shared leadership to be an important predictor of problem solving quality in virtual teams of social workers. Perhaps most relevant in terms of the current model. Hooker and Csikszentmihalyi (2003) found shared leadership to be an important ingredient in creativity in research and development labs. Their case study reveals that shared leadership. under certain conditions. can enhance the conditions for flow (Csikszentmihalyi, 1988, 1990). which in turn bolsters the creative process. Accordingly. we expect shared leadership to result in enhanced organizational learning. The following proposition more formally captures the essence of our logic on the linkage between virtuous shared leadership and organizational learning.

P5. Virtuous shared leadership is positively related to organizational learning.

\section{Implications}

The theoretical model we presented has multiple implications. Below we first identify the key research implications before proceeding to the practical implications.

\section{Research Implications}

Several important research implications are relevant to the current model. First. there is a notable dearth of research dealing with how virtuous leadership might ultimately result in organizational outcomes. Indeed. it is a challenging area in which to conduct research. Although 
many survey measures of leadership exist (e.g., Bass, 1985; Conger and Kanungo, 1998), comparatively little has been done to measure virtuous leadership. Nonetheless, the work of Manz and Sims and colleagues on SuperLeadership (e.g., Manz and Sims, 1990, 1991, 2001), alternatively labeled as empowering leadership (e.g., Pearce and Sims, 2002), provides a very useful starting point for launching work in the area of virtuous leadership and its impact in organizations.

Second, the temporal nature of the model presented here would suggest the need for longitudinal research. Issues such as organizational learning indeed take time to develop. Accordingly one might assess the antecedents at an early stage of research, virtuous vertical leadership at an intermediate stage, shared virtuous leadership at a later stage and organizational learning at a final stage. Clearly, experimental work might also be useful in regard to identifying the causal nature of these relationships.

Third, levels of analysis issues are relevant to the current model. The model includes individual-level, group-level and organizational level phenomena. The work of Kozlowski and Klein (2000) is relevant to research of this nature. They proposed that "bottom up processes" portray how lower-level properties emerge to form collective phenomena (Kozlowski and Klein, 2000, 15). Relevant to the concept of organizational learning, it is possible for emergence to occur through compilation, whereby there is theoretical reason to expect that lower-level properties may sometimes emerge in a discontinuous manner, The result is a collective-level phenomenon with configural properties. Kozlowski and Klein (2000) describe how unit properties conceptualized in configural terms are relatively rare in the organizational literature, although they are not rare in actual organizations. More specifically, they note that according to dispersion theory, non-uniform phenomena characterized by potential disagreement, competition, coalition formation, and so forth, may indeed be quite common.

In the present model, if vertical and shared leadership emerge in a configural manner, this would be a sign of the type of personalized leadership discussed earlier. That is, in the case of the vertical leader, while some followers might be enamored by the leader and attribute virtuous qualities, others might pick up on fraudulent or self-serving tendencies. As such. we would expect that compilation or configural properties of leader emergence to not be in line with the model shown in Figure 1. Instead, compositional or isomorphic models would be more in line with our model (Kozlowski and Klein, 2000). Such a model would entail the emergence of relatively uniform perceptions of virtuous leadership among followers. 


\section{Practical Implications}

There are several important practical implications that can be derived from the model that we have presented. Our model specifies that personal characteristics and environmental cues may play parts in the enactment of virtuous leadership. While codes of ethics seem a useful starting point, we contend a far more comprehensive approach is warranted. For instance, given that potential leaders can vary in their responsibility disposition, leader selection systems would appear to be a particularly important component of the organization's environment that not only signals what is valued, but also helps to reinforce those values.

While we articulated a distinction between those who have a personalized versus a socialized need for power, identifying and clearly separating these two drives can be challenging. This is particularly true because those who are high in the need for personalized power are also generally quite skilled at impression management (Giacalone, et al., 1998). Couple this with the fact that the way leaders are selected is often a less-than-rigorous process, and this is true even at the top of organizations (Charan, 2005). As such, leader selection requires serious attention. Accordingly, one potential strategy would be the employment of sophisticated psychological testing as an important component of the leader selection process, at all levels of the organization. For example, Hogan and Hogan (2001) offer an approach that has promise for uncovering the hidden motives of would be narcissistic leaders. Nonetheless, this is an area that would benefit from increased attention.

Leadership development is another important environmental cue that can both signal the importance of virtuous behavior and educate would-be leaders in virtuous approaches to leadership. Unfortunately, evidence suggests that organizations rarely provide sufficient training and development (Pearce, 2004). Moreover, the vast majority of leadership development is focused on those individuals who are currently in formal leadership positions or have been identified as leadership candidates, as opposed to providing leadership skills learning opportunities to the wider work force which typically represents an important source of leadership for the future (Cox, Pearce, and Sims, 2003).

Perhaps this lack of attention to leadership development accounts for the general level of dissatisfaction with leaders that is so prevalent in organizations (Cranny, Smith, and Stone, 1992; Fisher and Locke, 1992). After "satisfaction with pay," "satisfaction with leadership" is generally the second most dissatisfying aspect of most employees' organizational lives (Hackman and Oldham, 1980), and this is quite consistent across a broad assortment of contexts, ranging from service workers. to employees in 
the machine trades, to professional and technical employees, and even to the ranks of management. Accordingly, the development of virtuous leadership, both vertical and shared, is an area that would benefit from emphasis in organizations.

Reward systems appear to be another important environmental cue when it comes to encouraging virtuous leadership. People search for cues about what is and what is not rewarded in their organizations. They subsequently engage in (or at least create the appearance that they engage in) those behaviors that they believe are rewarded. Unfortunately, organizational reward systems are often out of synch with the desires of those who create the reward systems (Kerr and Jermier, 1978). It is naïve, however, to suggest that simply paying people to be virtuous will miraculously result in virtuous leadership across the board. Realistically, we can expect that some people may not be motivated to behave in a virtuous manner. Again, this is where leader selection and development systems may prove important.

While we have highlighted several important environmental cues that can aid in the development of virtuous leadership, we do not think this is a comprehensive list of all that can be done to encourage virtuous leadership. Rather we illustrated these cues because they seem to be representative of what can be managed and seem to apply across organizational contexts. We think that when it comes to managing environmental cues in support of virtuous leadership, a holistic, systems approach is warranted. The key, it would appear, is to have integrated and aligned systems that collectively support the development of virtuous leadership in organizations.

\section{Conclusion}

We have attempted to shed light on the concept of virtuous leadership. We specified two potential antecedents of virtuous vertical leadership. Specifically, we identified the personal characteristic of responsibility disposition and environmental cues as potential predictors of subsequent virtuous leadership. Moreover, we articulated how virtuous vertical leadership might result in virtuous shared leadership. We also indicated how both vertical and shared virtuous leadership might act as key factors in the creation of organizational learning. Importantly, we identified several important research implications of our theoretical model. Finally. we illustrated several practical considerations when it comes to developing and enhancing virtuous leadership. Clearly, virtuous leadership deserves more theoretical and empirical attention. 


\section{References}

Avolio, B. J., Gardner, W. L., Walumbwa, F. O., Luthans, F., and May, D. R. (2004) Unlocking the mask: A look at the process by which authentic leaders impact follower attitudes and behaviors. The Leadership Quarterly, 15, 801-823.

Avolio, B. J., Jung, D., Murry, W., and Sivasubramaniam, N. (1996) Building highly developed teams: Focusing on shared leadership process, efficacy, trust, and performance. In M. M. Beyerlein, D. A. Johnson, and S. T. Beyerlein (eds.), Advances in Interdisciplinary Studies of Work Teams, Greenwich: JAI Press, Inc. 173-209

Bass, B. M. (1985) Leadership and Performance Beyond Expectations, New York: Free Press.

Bass, B. M., and Steidlmeier, P. (1999) Ethics, character, and authentic transformational leadership behaviour, The Leadership Quarterly, 10, 181-217.

Bass, B. M., Waldman, D. A., Avolio, B. J., and Bebb, M. (1987) Transformational leadership and the falling dominoes effect, Group and Organization Studies, 12, 73-87.

Burke, C. S., Fiore, S. M., and Salas, E. (2003) The role of shared cognition in enabling shared leadership and team adaptability, In C. L. Pearce and J. A. Conger (eds.), Shared Leadership: Reframing the Hows and Whys of Leadership, Thousand Oaks, CA: Sage, 103-122

Burns, J. M. (1978) Leadership, New York: Harper Row.

Charan, R. (2005) Ending the CEO succession crisis, Harvard Business Review, February: 28-37.

Conger, J. A., (1990) The dark side of leadership, Organizational Dynamics. 19(2): 44-55.

Conger, J. A., and Kanungo, R. N. (1998) Charismatic Leadership in Organizations, Thousand Oaks, CA: Sage Publications.

Conger, J. A. and Pearce, C. L. (2003) A landscape of opportunities: Future research on shared leadership. In C. L. Pearce and J. A. Conger (Eds.) Shared leadership: Reframing the Hows and Whys of Leadership, Thousand Oaks, CA: Sage, 285-303.

Cox, J. F., Pearce, C. L. and Sims, H. P., Jr. (2003) Toward a broader agenda for leadership development: Extending the traditional transactional-transformational duality by developing directive, empowering and shared leadership skills, In S. E. Murphy and R. E. Riggio 
(eds.) The Future of Leadership Development, Mahwah, NJ: Lawrence Erlbaum, 161-180.

Cranny, C. J., Smith, P. C., and Stone, E. F. (eds.) (1992) Job Satisfaction: How People Feel About Their Jobs And How It Affects Their Performance. New York: Lexington Books.

Crossan, M., Lane, H., and White, R. (1999) An organizational learning framework: From intuition to institution, Academy of Management Review, 24(3), 522- 538.

Csikszentmihalyi, I. (1988) Flow in historical context: The case of the Jesuits, In M. Csikszentmihalyi and I. Csikszentmihalyi (eds.), Optimal Experience: Psychological Studies of Flow in Consciousness, Cambridge: Cambridge University Press.

Csikszentmihalyi, M. (1990) Flow: The Psychology of Optimal Experience, New York: Harper Collins.

Csikszentmihalyi, M. (1993) The Evolving Self, New York: HarperCollins.

Csikszentmihalyi, M. (2003) Good Business: Flow, Leadership and the Making of Meaning, New York: Viking.

Donaldson, T., and Preston, L. (1995) The stakeholder theory of the firm: Concepts, evidence and implications, Academy of Management Review, 20(1): 65-92.

Ensley, M. D., and Pearce, C. L. (2000) Assessing the influence of leadership behaviors on new venture TMT processes and new venture performance. Presented to the 20th Annual Entrepreneurship Research Conference, Babson Park, Massachusetts, June, 2000.

Fisher, C. D., and Locke, E. A. (1992) The new look in job satisfaction research and theory, In C. J. Cranny, P. C. Smith, and E. F. Stone (Eds.) Job Satisfaction: How People Feel About Their Jobs and How It Affects Their Performance, New York: Lexington Books, 165-194.

Freeman, R. E. (1984) Strategic Management: A Stakeholder Approach, Boston: Pitman.

Gardner, H., Damon, W., and Csikszentmihalyi, M. (2001) Good Work: When Excellence And Ethics Meet, New York: Basic Books.

Gardner, W. L., and Avolio, B. J. (1998) The charismatic relationship: A dramaturgical perspective, Academy of Management Review, 23(1), 32-58.

Giacalone, R. A., Knouse, S. B., and Pearce, C. L. (1998) The education of leaders: Impression management as a functional competence, Journal of Management Systems, 10(2), 67-80. 
Hackman, J. R. and Oldham, G. R. (1980) Work Redesign, Reading, MA: AddisonWesley.

Hogan, R. (1994) Trouble at the top: Causes and consequences of managerial incompetence, Consulting Psychology Journal: Practice \& Research, 46, 9-15.

Hogan, R., Curphy, G. J., and Hogan, J. (1994) What we know about leadership effectiveness and personality, American Psychologist, 49, 493-504.

Hogan, R., and Hogan, J. (2001) Assessing leadership: A view from the dark side, International Journal of Selection \& Assessment, 9, 40-51.

Hooker, C. and Csikszentmihalyi, M. (2003) Flow, shared leadership and creativity, In C. L. Pearce and J. A. Conger (eds.) Shared leadership: Reframing the Hows and Whys of Leadership, Thousand Oaks, CA: Sage.

Houghton, J., Neck, C. P., and Manz, C. C. (2003) Self-leadership and superleadership: The heart and the art of creating shared leadership in teams, In C. L. Pearce and J. A. Conger (eds.), Shared leadership: Reframing the Hows and Whys of Leadership, Thousand Oaks, CA: Sage, 123-140.

House et al. (1999) Cultural influences on leadership and organizations: Project GLOBE, Advances in Global Leadership, 1, 171-233.

House, R. J., and Howell, J. M. (1992) Personality and charismatic leadership, The Leadership Quarterly, 3, 81-108.

Howell, J. M., and Avolio, B. J. (1992) The ethics of charismatic leadership: Submission or liberation? Academy of Management Executive, 6, 43-54.

Kanungo, R. N. (2001) Ethical values of transactional and transformational leaders, Canadian Journal of Administrative Sciences, 18, 257-265.

Kerr, S. and Jermier, J. M. (1978) Substitutes for leadership: Their meaning and measurement, Organizational Behavior and Human Performance, 22(3), 1-14.

Kets de Vries, M. F. R. (1993) Leaders, Fools, and Impostors, San Francisco: Jossey-Bass.

Kohlberg, L. (1976) Moral stages and moralization: The cognitive-developmental approach, In T. Likona (Ed.), Moral Development and Behavior: Theory, Research, and Social Issues, Austin, TX: Holt, Rinehart and Winston, 31-53.

Kozlowski, S. W. J., and Klein, K. J. (2000) A multilevel approach to theory and research in organizations: Contextual, temporal, and emer- 
gent processes, In K. J. Klein and S. W. J. Kozlowski (eds.), Multilevel Theory, Research, and Methods in Organizations: Foundations, Extensions, and New Directions, San Francisco: Jossey-Bass, 3-90.

Kuhnert, K. W. (1994) Transforming leadership: Developing people through delegation, In B. M. Bass and B. J. Avolio (eds.), Improving Organizational Effectiveness Through Transformational Leadership, Thousand Oaks, CA: Sage, 10-25.

Kuhnert, K. W., and Lewis, P. (1987) Transactional and transformational leadership: A constructive/developmental analysis, Academy of Management Review, 12, 648-657.

Lawler, E. E., III, and Finegold, D. (2000) Individualizing the organization: Past, present, and future, Organizational Dynamics, 29(1), 1-15

Lord, R. G., and Brown, D. J. (2001) Leadership, values, and subordinates self-concepts. The Leadership Quarterly, 12, 133-152

Lord, R. G., and Brown, D. J. (2004) Leadership Processes and Follower SelfIdentity. Mahwah, New Jersey: Lawrence Erlbaum.

Maccoby, M. (2004) Narcissistic leaders: The incredible pros, the inevitable cons, Harvard Business Review, 82, 92-101.

Manz, C. C., and Sims, H. P., Jr. (1990) SuperLeadership, New York: Berkeley Books.

Manz, C. C., and Sims, H. P., Jr. (1991) SuperLeadership: Beyond the myth of heroic leadership, Organizational Dynamics, 19, 18-35.

Manz, C. C. and Sims, H. P., Jr. (2001) The New SuperLeadership: Leading Others to Lead Themselves, San Francisco: Berrett-Koehler.

Mendonca, M. (2001) Preparing for ethical leadership in organizations, Canadian Journal of Administrative Sciences, 18, 266-276.

Mischel, W. (1977) The interaction of person and situation, In D. Magnusson and N. S. Ender (eds.), Personality at the Crossroads: Current Issues in Interactional Psychology. Hillsdale, NJ: Erlbaum.

Pearce, C. L. (1997) The determinants of change management team effectiveness: A longitudinal investigation. $\mathrm{PhD}$ dissertation, University of Maryland, College Park, MD.

Pearce, C. L. (2004) The future of leadership: Combining vertical and shared leadership to transform knowledge work, Academy of Management Executive, 18(1), 47-57.

Pearce, C. L., and Conger, J. A. (eds.) (2003) Shared Leadership: Reframing the Hows and Whys Leadership, Thousand Oaks, CA: Sage Publications. 
Pearce, C. L., and Ensley, M. D. (2004) A reciprocal and longitudinal investigation of the innovation process: The central role of shared vision in product and process innovation teams (PPITs), Journal of Organizational Behavior, 25, 259.

Pearce, Craig L., and Charles C. Manz (2005) The new silver bullets of leadership: The importance of self and shared leadership in knowledge work, Organizational Dynamics, 34(2): 130-140.

Pearce, C. L., and Sims, H. P., Jr. (2002) Vertical versus Shared Leadership as Predictors of the Effectiveness of Change Management Teams: An Examination of Aversive, Directive, Transactional, Transformational, and Empowering Leader Behaviors, Group Dynamics: Theory, Research, and Practice, 6(2), 172-197.

Pearce, C. L., Sims, H. P., Jr., Cox, J. F., Ball, G., Schnell. E., Smith, K. A., and Trevino, L. (2003) Transactors, transformers and beyond: A multimethod development of a theoretical typology of leadership, Journal of Management Development, 22(4), 273-307.

Pearce, C. L., Yoo, Y., and Alavi, M. (2004) Leadership, social work and virtual teams: The relative influence of vertical vs. shared leadership in the nonprofit sector, In R. E. Riggio and S. Smith-Orr (eds.) Improving Leadership in Nonprofit Organizations, San Francisco: Jossey Bass, 180- 203.

Rauch, C. F., and Behling, O. (1984) Functionalism: Basis for an alternative approach to the study of leadership, In J. G. Hunt, D. M. Hosking, C. A. Schriesheim, and R. Stewart (eds.), Leaders and Managers: International Perspectives on Managerial Behavior and Leadership, Elmsford, NY: Pergamon Press, 45-62.

Sashkin, M. (1988) The visionary leader. In J. A. Conger and R. N. Kanungo (eds.), Charismatic Leadership: The Elusive Factor in Organizational Effectiveness, San Francisco: Jossey-Bass, 122-160.

Seligman, M., and Csikszentmihalyi, M. (2000) Positive psychology: An introduction, American Psychologist, 55(1), 5-14.

Senge, P. M. (1990) The Fifth Discipline: The Art and Practice of The Learning Organization, New York: Doubleday.

Shamir, B., House, R. J., and Arthur, M. B. (1993) The motivational effects of charismatic leadership: A self-concept based theory, Organization Science, 4, 577-594.

Shamir, B., and Lapidot, Y. (2003) In C. L. Pearce and J. A. Conger (eds.), Shared leadership: Reframing the Hows and Whys of Leadership, Thousand Oaks. CA: Sage, 285-303. 
Turner, N., Barling, J., Epitropaki, O., Butcher, V., and Milner, C. (2002) Transformational leadership and moral reasoning, Journal of Applied Psychology, 87, 304-311.

Vera, D., and Crossan, M. (2004) Strategic leadership and organizational learning, Academy of Management Review, 29, 222-240.

Waldman, D. A., Ramirez, G. G., House, R. J., and Puranam, P. (2001) Does leadership matter?: CEO leadership attributes under conditions of perceived environmental uncertainty, Academy of Management Journal, 44, 134-143.

Waldman, D. A., Siegel, D., and Javidan, M. (2005) CEO transformational leadership and corporate social responsibility. Revision under review at the Journal of Management Studies.

Waldman, D. A., and Yammarino, F. J. (1999) CEO charismatic leadership: Levels-of- management and levels-of-analysis effects, Academy of Management Review, 24, 266-285.

Weaver, G. R., Trevino, L. K., and Cochran, P. L. (1999) Integrated and decoupled corporate social performance: Management commitments, external pressures, and corporate ethics practices, Academy of Management Journal, 42, 539-552.

Winter, D. G. (1991) A motivational model of leadership: Predicting longterm management success from TAT measures of power motivation and responsibility, The Leadership Quarterly, 2, 67-80.

Yuki, G. (2002) Leadership in Organizations (5th ed.). Upper Saddle River, NJ: Prentice-Hall. 